\title{
Dos exposiciones en el Centro de Extensión
}

\section{Tanteando la ciudad \\ Trabajos de tesis en el Doctorado en Arquitectura y Estudios Urbanos}

Exposición en la Galería de Arte del Centro de Extensión, Pontificia Universidad Católica de Chile

(18 de octubre / 23 de noviembre 2007)

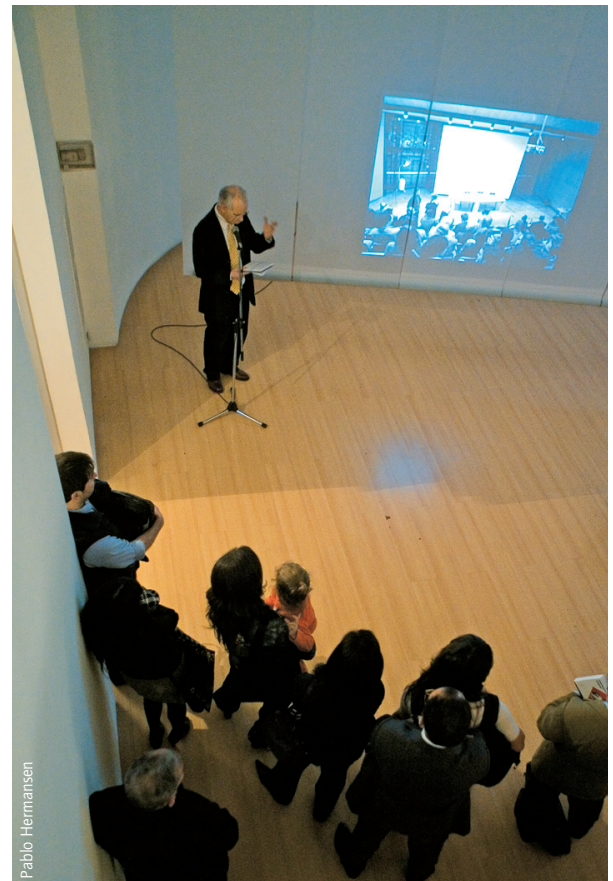

La exposición Tanteando la Ciudad se propuso mostrar, a través de medios visuales y en un tono accesible al público general, los contenidos de diversas investigaciones que alrededor de la ciudad, se llevan a cabo en las tesis actualmente en desarrollo en el Doctorado en Arquitectura y Estudios Urbanos de la Pontificia Universidad Católica de Chile. Se trataba de realizar un esfuerzo por acercar de manera sensible al ciudadano común a un conjunto de esfuerzos por comprender las realidades y problemas urbanos hechos por los doctorandos a través de sus tesis. Ellas constituyen el corazón mismo del programa y uno de los bienes más preciados que la universidad puede exhibir.

Cuando el Doctorado en Arquitectura y Estudios Urbanos comenzó a ser concebido en el seno de la Facultad de Arquitectura, Diseño y Estudios Urbanos, se propuso ser algo más que un programa de estudios. Se quería que fuese también capaz de mostrar y poner bajo la luz de lo público sus intereses, sus preguntas, sus desvelos. Que fuese, en síntesis, capaz de contribuir a que la reflexión sobre la ciudad contemporánea y sus problemas alcanzara a los ciudadanos y que a través de ella pudiese mejorar el nivel de la discusión pública sobre estos asuntos. La posibilidad de esta exposición, ofrecida por el Centro de Extensión, proporcionó una ocasión privilegiada para concretar dicho propósito.

Llevarla a cabo exigió, sin embargo, responder una pregunta difícil: ¿cómo se muestra un doctorado? Pareció que no había mejor manera de hacerlo que a través de sus tesis: haciendo visibles su materia, su trabajo, sus preguntas. Ello exigió a cada uno de los tesistas un esfuerzo de síntesis, además de la capacidad de hacer visible su trabajo en el sentido más material y profundo del término.

Finalmente, se decidió que la exposición mostrara las tesis en tres instancias: la primera, una presentación digital continua que exhibía una sucesión de imágenes y textos significativos acerca de cada una de las tesis. La segunda, un afiche acompañado de un breve texto explicativo que explicara de la manera más sintética, el contenido de cada tesis. Por último, el contendido del afiche se reproducía en postales disponibles para el público, de manera que cualquier interesado pudiese llevar consigo un registro de uno o varios de los trabajos. Contando con estos medios, se presentaron alrededor de 30 trabajos que abordaban problemas históricos, culturales o sociales referidos a la ciudad contemporánea y muy frecuentemente a Santiago.

Pero las tesis por sí solas no daban cuenta del Doctorado a cabalidad. Si como alguna vez señaló el rector Juan de Dios Vial Correa, la universidad es una forma de vida, mostrar un doctorado es también mostrar un lugar y unos paisajes donde esa vida académica florece. Es por ello que la exposición incorporó también un registro fotográfico de lo que ha sido la vida diaria del doctorado: desde los seminarios hasta las convivencias. De este modo, la presentación digital que muestra las tesis tiene el contrapunto de otra que muestra la cotidianeidad de esa vida académica.

Hacia el exterior, la exposición constituye, como se ha dicho, un esfuerzo por dar a conocer lo que en el programa se hace, se piensa y se estudia. Sin embargo, ella también permite al propio programa lograr una visión más total y más articulada de su trabajo. Ese conjunto de tesis en desarrollo representado en la sucesión de imágenes, en los afiches o en las postales, unido al registro de la vida académica que las generó, constituyen un vívido retrato del Doctorado en Arquitectura y Estudios Urbanos que, sin la exposición, no habría sido visible aún para sus propios protagonistas.
01

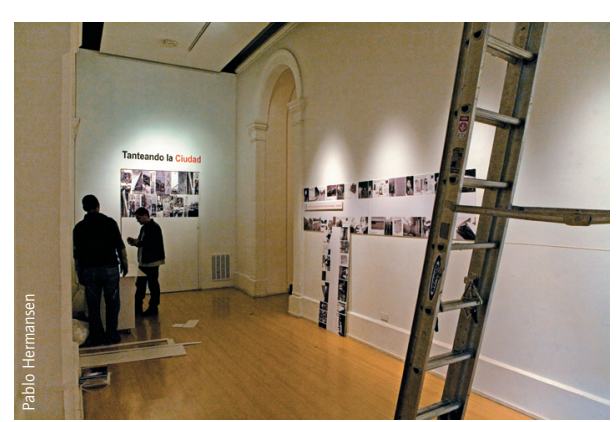

02

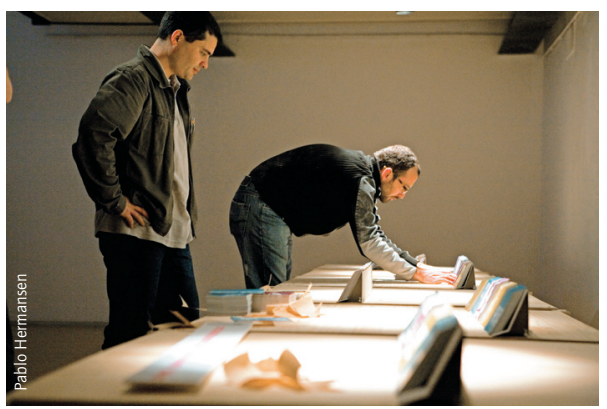

03

01 Presentación de Fernando Pérez Oyarzun, jefe programa Doctorado e Arquitectura y Estudios Urbanos

02-03 Vistas generales de la exposición.

Comité Organizador Philippe Blanc, Umberto Bonomo, Andrea Masuero, Fernando Pérez, Gabriela Raposo Producción Loreto Villarroel

Participantes en el montaje Eduardo Canteros, Simón Castillo, Tomás Errázuriz, Felipe Fontecilla, Pablo Hermansen, Danilo Lagos, Christian Matus, Daniel Opazo, Francisco Quintana, Paul Reid; Ana María Reid, Álvaro Salas, Alberto Texido, José Ignacio Vielma Diseño de afiches y postales Vivian Klein Diseño presentación digital Diego Villalón 